\title{
EKONOMIA WOBEC POCZUCIA SZCZĘŚCIA
}

\section{WSTĘP}

W naukach społecznych trwa nieustanna dyskusja nad pojęciem i odczuwaniem szczęścia. Opublikowany przed kilkudziesięciu laty Traktat o szczęściu Władysława Tatarkiewicza ${ }^{1}$ był jednym $\mathrm{z}$ wielu głosów i zarazem stanowił uzupełnienie dotychczasowych przemyśleń, jak również mógł stanowić inspirację do dalszych dociekań dla kolejnych przedstawicieli wielu dyscyplin naukowych.

W dyskusji nad poczuciem szczęścia swoją obecność mocno zaznaczają nauki ekonomiczne, przy czym poglądy formułowane przez ekonomistów uwzględniaja również osiagnięcia badaczy z innych dyscyplin naukowych. Celem tego artykułu jest próba odpowiedzi na pytanie: Czy pomiar szczęścia w ogóle jest możliwy?

\section{DEFINICJA SZCZĘŚSIA}

Arystoteles pisal, że być szczęśliwym to „dobrze żyć i dobrze się mieć”, a szczęście to zadowolenie trwałe 2 . Współcześnie termin „szczęście” jest różnorodnie rozumiany w języku potocznym oraz naukowym. W pierwszym znaczeniu jedna z definicji (powtarzająca się w językach: angielskim, niemieckim, francuskim, rosyjskim i czeskim) określa szczęście jako stan najwyższego zadowolenia ${ }^{3}$, jednakże nie jest ona jedyną ${ }^{4}$. Z naukowego punktu widzenia szczęście jest odmiennie definiowane przez poszczególnych badaczy zajmujących się tym terminem. Szczęście określane jest m.in. jako: zadowolenie doświadczane w kontaktach z otoczeniem (G. Beusekom-Fretz), szczególny rodzaj emocji i podsumowanie przyjemnych i nieprzyjemnych doświadczeń z przeszłości (M. W. Fordyce), pozytywna ocena własnego życia jako całości (R. Veenhoven),

\footnotetext{
${ }^{1}$ W. Tatarkiewicz, O szczęściu, PWN, Warszawa 1985.

${ }^{2}$ Arystoteles, Etyka nikomachejska, przeł. D. Gromska, t. 1, 1956 s. 7, za: W. Tatarkiewicz, op. cit., s. 31.

${ }^{3}$ R. Veenhoven, Conditions of Happiness, Reidel, Dordrecht 1984.

${ }^{4}$ J. Czapiński, Psychologia szczęścia, Pracownia Testów Psychologicznych, Warszawa 1994, s. 11.
} 
czy też zadowolenie z życia lub intensywność przyjemnych emocji (M. Argyle) ${ }^{5}$. Takie ujęcie to nic nowego, według Tatarkiewicza szczęście to bowiem pełne i trwałe zadowolenie z życia ${ }^{6}$.

Z kolei Janusz Czapiński - socjolog - szczęście opisuje jako subiektywnie postrzeganą lub odczuwana pomyślność, dobry stan własnego życia, i dlatego też pojawia się często pojęcie dobrostanu psychicznego jako synonim szczęścia?

\section{EKONOMIA SZCZĘŚSIA}

Ekonomiści klasyczni w swoich rozważaniach koncentrowali się i koncentruja na gospodarowaniu, widząc $\mathrm{w}$ nim czynnik zapewniający sukces jednostce. Najczęściej przyjmowaną przez nich koncepcją jest homo oeconomicus, zgodnie z którą cel człowieka wyraża się w maksymalizowaniu użyteczności oraz zysku. Założenie teorii użyteczności, według której każdy dąży do maksymalizacji zadowolenia, nie jest jednak równoznaczne z dążeniem do szczęścia. Jeremy Bentham sformułował „zasadę największego szczęścia”, według której każdy powinien dążyć do największego dobra i największego szczęścia w największej ilości. Wszystkie wybory i odczucia związane z tymi działaniami przekładane są na poziom użyteczności. Użyteczność jest tu rozumiana jako satysfakcja, przyjemność, czy też zadowolenie. Poglądy Jeremy'ego Benthama w tej kwestii kontynuował John S. Mill. Podejście do problemu użyteczności uległo jednak modyfikacji za sprawą Vilfreda Pareta, który założył, że na poziom zadowolenia wpływ ma wybór pomiędzy różnymi opcjami. Jednakże dążenie do maksymalnej użyteczności nie musi oznaczać dążenia do szczęścia8

W drugiej połowie XX w. zaczęła się rozwijać ekonomia szczęścia (economics of happines). Wyjaśnienia w tym miejscu wymaga fakt, że szczęście do lat sześćdziesiątych XX w. było przedmiotem zainteresowania filozofów. Następnie stało się obiektem rozważań socjologów i psychologów. Założyli oni, że jednym z potencjalnych źródeł szczęścia człowieka mogą być pieniądze. Kilkanaście lat później ekonomiści „zapożyczyli” te założenia, a wskaźniki subiektywnego dobrostanu wykorzystali jako miary użyteczności pieniędzy. W ten sposób połączenie rozważań psychologów, socjologów i ekonomistów przyczyniło się do popularyzacji interdyscyplinarnych badań, których tematem była jednoczesna ocena bogactwa i szczęścia człowieka jako jego podstawowych, a zarazem powiązanych ze sobą celów życiowych ${ }^{9}$.

${ }^{5}$ G. Beusekom-Fretz, De democratisering van het geluk, v. Loghem Slaterus, Deventer 1973; M. W. Fordyce, Happiness Its Daily Variation and Its Realtion to Values, United Stated International University, San Diego, California, 1972; R. Veenhoven, op. cit.; M. Argyle, The Psychology of Happiness, Methuen, London 1987, za: J. Czapiński, op. cit., s. 11.

${ }^{6}$ W. Tatarkiewicz, op. cit., s. 31.

7 J. Czapiński, op. cit., s. 12.

8 Szerzej: P. Michoń, Ekonomia szczęścia, Dom Wydawniczy Harasimowicz, Poznań 2010, s. 24-38; zob. też: R. Rogowski, Szczęściodajność pieniadza, w: D. Markowski, P. Setlak (red.), Społeczeństwo konsumpcyjne. Uwarunkowania spoteczne i kulturowe, PWSZ im. prof. Stanisława Tarnowskiego w Tarnobrzegu, Tarnobrzeg 2008, s. 283-306.

9 J. Czapiński, Ekonomia szczęścia i psychologia bogactwa, „Nauka” 2012, nr 1, s. 51. 
W ujęciu makroekonomicznym do podstawowych kategorii mierzących bogactwo narodów zaliczany jest produkt krajowy brutto. Aby zaś ocenić poziom rozwoju gospodarczego kraju i przeciętny standard życiowy ludności, stosuje się także PKB per capita. Ekonomiści zajmujący się ekonomią szczęścia dowodza, że oprócz bogactwa gospodarki należy jednocześnie podejmować starania mierzenia szczęścia obywateli danego kraju. Z przytoczonych we wstępie definicji wynika, że szczęście nie jest przypisane do społeczeństwa, a do jego jednostek. Szczęście jest pojęciem subiektywnym, ekonomiści zaś starają się je zobiektywizować. W tym celu podejmowane są badania ankietowe, aby porównywać poziom szczęścia w różnych grupach społecznych, krajach, czy też w różnym czasie. Ludzie sami oceniają poziom własnego dobrobytu, a przez ich subiektywne odczucia próbuje się uzyskać odpowiedź na pytania, czym jest szczęście (według badanych) oraz jakie czynniki je determinuja. W ramach tak prowadzonych analiz można rozpoznać wpływ na poziom szczęścia takich czynników, jak: poziom dochodu, różnice w dochodach, stan zdrowia, zatrudnienie, bezrobocie, małżeństwo, płeć, rasa, zanieczyszczenie środowiska i warunki naturalne, czy też klimat ${ }^{10}$.

Wychodząc z oczywistego założenia, że współczesny świat charakteryzuje się specyficznymi przemianami społeczno-gospodarczymi, ważnym problemem staje się ich pomiar. Jak już wspomniano, PKB jest najpopularniejszym miernikiem aktywności gospodarczej. Jednakże jako miara dobrobytu społecznego, dobrostanu i szczęścia może zawodzić. Podejmowano więc wiele prób stworzenia miar rozwoju społeczno-gospodarczego, dobrobytu społecznego, dobrostanu kraju i jakości życia mieszkańców, w tym także szczęścia. Na przykład:

- w 1972 roku Królestwo Bhutanu jako pierwsze na świecie oficjalnie zlikwidowało wskaźnik PKB i zastapiło go innym - wskaźnikiem Narodowego Szczęścia Brutto ${ }^{11}$;

- w 1990 r. agenda ONZ UNDP wprowadziła wskaźnik rozwoju społecznego - Human Development Index, HDI ${ }^{12}$;

- wskaźnik dobrobytu, który nosi nazwę „miara krajowego rozwoju”, wprowadził rząd Wielkiej Brytanii, jednocześnie zachowując miernik PKB ${ }^{13}$;

- w 2008 r. prezydent Francji Nicolas Sarkozy powołał Komisję do spraw Pomiaru Gospodarki i Postępu Społecznego. Komisja, pracująca pod kierunkiem amerykańskiego profesora Josepha E. Stiglitza, udowadniała niewystarczalność, a zarazem zwodniczość miernika PKB w ocenie dobrobytu oraz wskazywała na niesatysfakcjonujące dotychczasowe miary postępu gospodarczego i jakości życia. Rekomendowała posługiwanie się w szerszym zakresie także innymi, mierzalnymi, obiektywnymi miarami dobrobytu, czy raczej dobrostanu, jak również subiektywnymi wskaźnikami szczęścia ${ }^{14}$;

${ }^{10}$ B. Czarny, Pieniadze szczęścia nie daja?, Warszawa 2010, www.ksap.gov.pl (dostęp: 2.02.2014).

11 Narodowe szczęście brutto (ang. Gross National Happiness - GNH) - wskaźnik funkcjonujaccy w Bhutanie od 1972 r.; wprowadził go ówczesny król Bhutanu - Jigme Singye Wangchuck, za: http://www.grossnationalhappiness.com/articles/ (dostęp: 31.03.2014).

12 Zob. http://hdr.undp.org/en/data (dostęp: 31.03.2014).

13 Zob. www.neweconomics.org.

14 J. S. Stiglitz, A. Sen, J.-P. Fitoussi, Bład pomiaru. Dlaczego PKB nie wystarcza, PWE, Warszawa 2013. 
- 2009 r. Komisja Europejska postulowała wprowadzenie centralnego europejskiego systemu mierzenia dobrobytu zamiast $\mathrm{PKB}^{15}$.

Inne alternatywne mierniki proponowane w zamian za PKB to m.in. ${ }^{16}: \mathrm{Na}$ rodowy Indeks Szczęścia ${ }^{17}$, Genuine Progress Indicator (GPI) ${ }^{18}$, Indeks Zrównoważonego Dobrobytu Ekonomicznego (Index of Sustainable Economic Welfare - ISEW) ${ }^{19}$, czy też Indeks Zrównoważonych Korzyści Netto (Sustainable Net Benefit Index - SNBI) ${ }^{20}$.

Ekonomia szczęścia, mimo wielu prób, nie wyjaśnia jednak problemu i pomiaru szczęścia w społeczeństwie, a wręcz przeciwnie wraz z nowymi badaniami i rozważaniami ekonomistów pojawiają się coraz to nowe pytania. Jedno z podstawowych pytań zadawanych przez ekonomistów brzmi: Czy bogactwo poprawia byt człowieka? Tym zagadnieniem zają się po raz pierwszy w $1974 \mathrm{r}$. Richard Easterlin. W artykule Does Economic Growth Improve the Human Lot? [Czy wzrost ekonomiczny zwiększa pomyślność ludzi?] stwierdził, że nie można wskazać wyraźnego związku między szczęściem a materialnym dobrobytem. Od tego czasu o braku zależności między dobrostanem a bogactwem zaczęto mówić jako o paradoksie, który z czasem został nazwany paradoksem Easterlina. Jego istota tkwi w tym, że ludzie zamożniejsi sa szczęśliwsi, ale wzrost ich dochodów nie prowadzi wcale do zwiększenia ich poczucia szczęśsia ${ }^{21}$.

Obecnie ciagle bezskutecznie próbuje się udzielić wyczerpującej odpowiedzi na wyżej postawione pytanie. Jako przykład można tutaj podać opracowanie Josepha Stiglitza, Amartyi Sena i Jeana-Paula Fitoussiego Btad pomiaru. Dlaczego PKB nie wystarcza. Autorzy, uczestniczący w ramach prac wspomnianej wcześniej Komisji do spraw Pomiaru Gospodarki i Postępu Społecznego, z jednej strony uważaja, że wzrost gospodarczy jest bardzo ważny w kształtowaniu poziomu zadowolenia społeczeństwa, ale równocześnie z drugiej dodaja że należy w ocenie szczęścia stosować także wskaźniki szczęścia ${ }^{22}$.

Kolejne pytanie, które jest przedmiotem zainteresowania ekonomii szczęścia brzmi: Jakie czynniki gwarantują szczęście ludzi? W tabeli 1 przedstawiono zestawienia czynników wpływających na odczuwanie szczęścia przez jed-

15 Komunikat Komisji do Rady i Parlamentu Europejskiego: Wyjść poza PKB. Pomiar postępu w zmieniającym się świecie, http://eur-lex.europa.eu/Notice.do?checktexts=checkbox\&v al=499855 (dostęp: 21.12.2013).

${ }_{16}$ J. Czapiński, Ekonomia szczęścia..., s. 68.

17 Zob. www.happyplanetindex.org; Y. K. Ng, Happiness Studies: Ways to Improve Comparability and Some Public Policy Implications, ,The Economic Record” 84/2008.

${ }_{18}$ C. Cobb, T. Halstead, J. Rowe, The Genuine Progress Indicator: Summary of Data and Methodology, Redefining Progress, San Francisco 1995.

${ }_{19}$ H. Daly, J. B. Cobb, For the Common Good: Redirecting the Economy Towards Community, the Environment, and a Sustainable Future, Beacon Press, Boston 1989.

${ }^{20}$ P. A. Lawn, An Assessment of the Valuation Methods Used to Calculate the Index of Sustainable Economic Welfare (ISEW), Genuine Progress Indicator (GPI), and Sustainable Net Benefit Index (SNBI), „Environment, Development and Sustainability” 7/2005, s. 185-208, http:// genuineprogress.net/wp-content/uploads/2013/01/lawn-gpi.pdf (dostęp: 31.03.2014).

${ }^{21}$ R. Easterlin, Does Economic Growth Improve the Human Lot?, w: P. A. David, M. W. Reder (red.), Nations and Households in Economic Growth, Academic Press, New York 1974.

${ }^{22}$ J. S. Stiglitz, S. Sen, J.-P. Fitoussi, op. cit. 
nostkę według rozważań wybranych autorów zajmujących się problematyka szczęścia w społeczeństwie.

Jak wynika z tabeli $1 \mathrm{w}$ literaturze przedmiotu pojawiło się na przestrzeni lat wiele różnorakich aspektów problemu szczęścia i jego determinant. Trudno jest wskazać na jednoznacznie spójne elementy wniosków badaczy zajmujących się szczęściem w społeczeństwie. Rozważania dotyczące ekonomii szczęścia prowadzone są nadal. Jako najważniejsze, a zarazem podstawowe, wskazywane są następujace tezy obecnego stanu wiedzy w ramach economics of happiness ${ }^{23}$ :

- poczucie szczęścia człowieka z jednej strony warunkowane jest poziomem dochodu, który jednocześnie ma istotny wpływ na konsumpcję. Z drugiej strony szczęście jest determinowane także innymi zmiennymi, jak np.: relacje rodzinne, relacje z ludźmi, stan zdrowia, czy też jakość środowiska;

- ważnym czynnikiem kształtującym poziom szczęścia pojedynczego człowieka jest relatywność jego dochodów w stosunku do innych osób. Im większe są względne różnice dochodów, tym częściej można obserwować spadek poziomu szczęścia w różnych, zwykle dosyć licznych, grupach społecznych.

- czynnikiem silnie wpływającym na spadek poziomu szczęścia ludzi jest bezrobocie;

- ludzie zakładaja, że poziom ich szczęścia w przyszłości wzrośnie, ponieważ przeceniają wpływ rosnącej bieżącej konsumpcji na przyszły poziom swojego zadowolenia;

- ekonomia szczęścia zakłada, że mieszkańcy krajów bogatszych sa szczęśliwsi, ale jednocześnie istnieje taka granica dochodu, powyżej której wzrost tego dochodu ma niewielki wpływ na podnoszenie poziomu szczęścia (paradoks Easterlina). Część naukowców zajmujących się tą tematyka, powołując się na coraz to nowe badania, dowodzi, że nie istnieje jednocześnie tak wysoki próg dochodu, powyżej którego zaniknęłaby całkowicie zależność pomiędzy wzrostem dochodu a wzrostem poczucia szczęścia ${ }^{24}$.

Z kolei jako najnowsze osiagnięcia w dziedzinie interdyscyplinarnych badań nad szczęściem, w których istotną rolę odgrywają rozważania ekonomiczne, można wskazać m.in. poglądy dotyczące ${ }^{25}$ :

- polityki szczęścia. W polityce szczęścia badaczy intrygują pytania o sposób i stopień wykorzystywania przez rządy wyników badań nad szczęściem. W ramach tych rozważań najczęściej przedstawiane są zasadnicze ustalenia badaczy szczęścia i oceny wiarygodności przeprowadzonych badań, a także ich przydatności w opracowywaniu polityki rządu (zobacz m.in.: D. Bok, E. Diener E, R. Lucas, U. Schimmack, J. Helliwell ${ }^{26}$ );

23 Por. B. Czarny, op. cit.

24 Por. D. Leonhardt, Maybe Money Does Buy Happiness After All, "The New York Times" 16 kwietnia 2008 r., http://www.nytimes.com/2008/04/16/business/16leonhardt.html?_r=1 (dostęp: 31.03.2014).

25 Por. J. Czapiński, Ekonomia szczęścia..., passim.

${ }^{26}$ D. Bok, The Politics of Happiness, PUP, Princeton 2010; E. Diener, R. Lucas, U. Schimmack, J. Helliwell (red.), Well-Being for Public policy, OUP, Oxford 2009. 
Tabela 1

Czynniki determinujące szczęście

\begin{tabular}{|c|c|c|}
\hline Autor podejścia & $\begin{array}{l}\text { Opracowanie } \\
\text { (rok wydania) }\end{array}$ & $\begin{array}{l}\text { Czynniki determinujące szczęście } \\
\text { jednostki }\end{array}$ \\
\hline R. Easterlin & $\begin{array}{l}\text { Does Economic Growth } \\
\text { Improve the Human Lot? } \\
\text { [Czy wzrost ekonomicz- } \\
\text { ny zwiększa pomyślność } \\
\text { ludzi?] (1974) }\end{array}$ & $\begin{array}{l}\text { Czynniki bezpośrednio zależne od jednostki, } \\
\text { m.in.: stan zdrowia, wykształcenie, najbliższe } \\
\text { otoczenie, relacje małżeńskie i rodzinne. Czynni- } \\
\text { ki pośrednie (niezależne od jednostki): elementy } \\
\text { osadzone w kulturze narodowej oraz w modelu } \\
\text { państwa (podkreślenie roli polityki społecznej). }\end{array}$ \\
\hline R. Layard & $\begin{array}{l}\text { Has Social Science } \\
\text { a Clue What Is Happi- } \\
\text { ness? Are We Getting } \\
\text { Happier? [Szczęście: Czy } \\
\text { nauki społeczne cokol- } \\
\text { wiek z tego rozumieja?] } \\
(2003)\end{array}$ & $\begin{array}{l}\text { Poczucie szczéścia i zadowolenia człowieka z ży- } \\
\text { cia zależy od wyniku porównania jego osiagnięć } \\
\text { z osiagnięciami innych osób. Jednostki porów- } \\
\text { nują zarówno swoje warunki materialne, jak } \\
\text { i niematerialne. }\end{array}$ \\
\hline R. Veenhoven & $\begin{array}{l}\text { Happiness and Hardship } \\
\text { [Szczęście i bieda] (2005) }\end{array}$ & $\begin{array}{l}\text { Determinanty szczęścia traktowane sa jako pięć } \\
\text { mierników. Pierwszy z nich to subiektywne od- } \\
\text { czucie szczęścia oceniane przez jednostkę, drugi } \\
\text { aspekt to długowieczność, trzecim warunkiem } \\
\text { szczęścia jest dochód narodowy brutto, za czwar- } \\
\text { ty wyznacznik uznaje się środowisko naturalne, } \\
\text { za piąty zaś element - najbliższe otoczenie. }\end{array}$ \\
\hline $\begin{array}{l}\text { B. Stevenson, } \\
\text { J. Wolfers, } \\
\text { D. Sacks }\end{array}$ & $\begin{array}{l}\text { Subjective Well-Being, } \\
\text { Income, Economic De- } \\
\text { velopment and Growth } \\
\text { [Subiektywne poczucie } \\
\text { dobrobytu w kontekście } \\
\text { dochodów i wzrostu go- } \\
\text { spodarczego] (2010) }\end{array}$ & $\begin{array}{l}\text { Zamożność jest istotnym czynnikiem gwaran- } \\
\text { tującym poziom szczęścia, a przeciętny poziom } \\
\text { satysfakcji z życia jest wyższy u osób w krajach } \\
\text { zamożniejszych niż w biedniejszych. }\end{array}$ \\
\hline $\begin{array}{l}\text { D. Kahneman, } \\
\text { A. Deaton }\end{array}$ & $\begin{array}{l}\text { Czy szczéście można ku- } \\
\text { pić? (2010) }\end{array}$ & $\begin{array}{l}\text { Nie istnieje algorytm szczéścia i pieniądza. Szczéście } \\
\text { można kupić, ale porównanie jego ceny jest niemożliwe } \\
\text { w przypadku różnych osób. Nieporównywalność może } \\
\text { wynikać z płci, wieku, wykształcenia, a także tego, że } \\
\text { różne dobra w różnych krajach mają różną wartość } \\
\text { emocjonalną. }\end{array}$ \\
\hline
\end{tabular}

Źródło: T. Wróblewski, Czy pieniqdze nie daja szczęścia?, Forbes, http://www.forbes.pl/tomasz-wroblewski-czy-pieniadze-nie-daja-szczescia-,artykuly,136031,1,3.html (dostęp: 31.03.2014). Zob. też: R. Easterlin, Does Economic Growth Improve the Human Lot?, w: P. A. David, M. W. Reder (red.), Nations and Households in Economic Growth, Academic Press, New York 1974; R. Layard, Has Social Science a Clue What is Happiness? Are We Getting Happier?, w: Lionel Robbins Memorial Lecture Series, 03-05 Mar 2003, London, http://eprints. lse.ac.uk/47425/1/_libfile_REPOSITORY_Content_Layard_Has\%20social\%20science\%20a\%20clue \%20 what\%20is\%20happiness_Has\%20social\%20science\%20a\%20clue\%20what\%20is\%20happiness\%20(LSE\%20 RO).pdf (dostęp: 31.03.2014); R. Veenhoven, Quality of Life in Individualistic Society: A Comparison of 43 Nations in Early 1990s, „Social Indicators Research” nr 48/1998; idem, Happiness and Hardship, w: L. Bruni, P. L. Porta (red.), Economics and Happiness, OUP, Oxford 2005; D. W. Sacks, B. Stevenson, J. Wolfers, Subjective Well-Being, Income, Economic Development and Growth, NBER Working Paper Nr. 16441 Issued in October 2010, http://www.nber.org/papers/w16441 (dostęp: 31.03.2014); D. W. Sacks, B. Stevenson, J. Wolfers, The New Stylized Facts about Income and Subjective Well-Being, „Emotion” 12(6), Dec. 2012, http://psycnet. apa.org/journals/emo/12/6/1181/ (dostęp: 31.03.2014); D. W. Sacks, B. Stevenson, J. Wolfers, Growth in Income and Subjective Well-Being over Time, http://www.hks.harvard.edu/inequality/Seminar/Papers/Stevenson13-1. pdf (dostęp: 31.03.2014); D. Kahneman, A. Deaton, High Income Improves Evaluation of Life but not Emotional Well-Bbeing, „Proceedings of National Academy of Science” 107, 2010, nr 38, September 21, http://www.pnas. org/content/107/38/16489.short (dostęp: 31.03.2014). 
- indywidualizmu. Znaczenie indywidualizmu w kształtowaniu szczęścia jednostki rośnie wraz ze wzrostem gospodarczym, który stwarza potencjalnie większe możliwości wyborów dla jednostki (dopasowanych do jej potrzeb; zob. A. Ahuvia, R. Fischer, D. Boer ${ }^{27}$ );

- inflacji i bezrobocia. W przypadku inflacji wskazuje się, że jej wysoki poziom może wpływać na obniżanie zadowolenia z życia. Badania dowodza także, że bezrobocie również obniża poziom szczęścia jednostek (zob. m.in.: R. DiTella, R. J. MAcCulloch, B. S. Frey $\left.{ }^{28}\right)$;

- procesu adaptacji jednostki, który odgrywa ważną rolę w budowaniu szczęścia jednostki (zob. R. DiTella, R. J. MAcCulloch ${ }^{29}$ ).

Ponadto pojawiają się wciąż nowe, bardziej rozszerzone wyniki interdyscyplinarnych badań traktujących o ekonomii szczęścia, w których istotną wagę przypisuje się porównaniom szczęścia w różnych społeczeństwach ${ }^{30}$.

\section{POMIARY SZCZĘŚCIA?}

Mimo że pojęcie „szczęścia” nie jest jednoznacznie zdefiniowane, a jego pomiar nadal budzi wiele dyskusji i kontrowersji, to jednak interdyscyplinarne światowe badania wypracowują mierniki wskazujące na poziom szczęścia, a tym samym stwarzają podstawy do opracowywania rankingów najszczęśliwszych społeczeństw na świecie. Wypracowane indeksy szczęścia w społeczeństwach powiązane sa z oceną jakości życia. Jakość życia to także pojęcie o interdyscyplinarnym charakterze ${ }^{31}$. W badaniach występuje zarówno opisowe,

27 A. C. Ahuvia, Indywidualizm-kolektywizm a kultury szczęścia, w: J. Czapiński (red.), Psychologia pozytywna, WN PWN, Warszawa 2004; R. Fischer, D. Boer, What Is More Important for National Well-Being: Money or Autonomy? A Meta-Analysis of Well-Being, Burnout, and Anxiety Across 63 Societies, „Journal of Personality and Social Psychology” 101, 2011.

${ }_{28}$ R. Di Tella, R.J. MacCulloch, Gross National Happiness as an Answer to the Easterlin Paradox?, „Journal of Development Economics” 86, 2008; B. S. Frey, Happiness. A Revolution in Economics, The MIT Press, Cambridge 2008.

${ }_{29}$ R. Di Tella, R. J. MacCulloch, op. cit.

${ }^{30}$ Por. E. Diener, J. F. Helliwell, D. Kahneman (red.), International Differences in Well-Being, OUP, Oxford 2010; A. K. Dutt, B. Radcliff (red.), Happiness, Economics and Politics, Edward Elgar, Cheltenham 2009; C. Graham, Happiness around the World, OUP, Oxford 2009; A. B. Krueger, Measuring Subjective Well-Being of Nations. National Accounts of Time Use and Well-Being, UC Press, Chicago 2009; A. Deaton, Income, Health, and Well-Being around the World: Evidence from the Gallup World Poll, ,Journal of Economic Perspectives” 22, 2008.

31 Elementy jakości życia zawierają w sobie treści psychologiczne, socjologiczne, filozoficzne, biologiczne i ekonomiczne. Obejmują materialne i niematerialne warunki życia, tworząc w ten sposób układ różnorodnych wymiarów życia ludzkiego. Dlatego trudno dokonywać pomiarów jakości życia i podejmować próby wartościowania ludzkiej egzystencji. Jedna z definicji mówi, że jakość życia to „[...] stopień satysfakcji człowieka (społeczeństwa) z całokształtu swej egzystencji [...]". Utożsamiana jest ona z dobrobytem materialnym aż po ocenę stanów osobistego zadowolenia, satysfakcji, czy też wręcz szczęścia, wynikającego z konsumpcji, otoczenia przyrodniczego, dobrego stanu zdrowia, pomyślności w życiu osobistym, pozycji zawodowej, statusu społecznego itp. Za: C. Bywalec, Konsumpcja a rozwój gospodarczy i społeczny, Wydawnictwo C. H. Beck, Warszawa 2010, s. 41-42. 
jak i wartościujące rozumienie tej kategorii. Podejście opisowe jest podstawa do rozróżnienia obiektywnej i subiektywnej jakości życia. Jakość życia dająca się mierzyć względnie zobiektywizowanymi miarami nie musi mieć jednak zbyt wiele wspólnego z poczuciem szczęścia, majacym raczej subiektywny charakter. Sprawia to, że często zdarza się, że poszczególne indeksy dotyczące jakości życia i szczęścia mają wspólne elementy składowe, często wzajemnie się przenikaja, uzupełniaja, czy też nawet traktowane są zamiennie. Konsekwencją takiej sytuacji może być również fakt, że w opracowaniach naukowych mówi się, że badane jest szczęście, gdy tymczasem ocenie podlega jakość życia.

W artykule uwagę zwrócono na wybrane wskaźniki oceniające poziom szczęścia i zadowolenia ${ }^{32}$ :

1. Światowa Ankieta Wartości (World Value Survey - WVS), w której respondenci od 1981 r. pytani są o następujące elementy życia: postrzeganie życia, środowisko, pracę, rodzinę, politykę i społeczeństwo, religię i etykę, narodowość. Badaniom podlega 97 krajów, a dobrana próba odzwierciedla $90 \%$ globalnej populacji. Na podstawie badań każdy z krajów może otrzymać notę od 0 do 200, gdzie 200 oznacza najwyższy stopień szczęśliwości, 100 zaś to stan, w którym nie można mówić ani o szczęściu, ani też o nieszczęściu. Według ostatniego rankingu WVS (opracowanego według danych głównie za lata 2005-2008) za najszczęśliwszy kraj na świecie uznana została Islandia ze wskaźnikiem o wartości 194,3, a następnie Nowa Zelandia (193,8), Norwegia $(192,8)$, Szwecja $(192,4)$ i Irlandia $(192,2)$. Dla porównania w tabeli 2 przedstawiono stopień szczęśliwości w krajach Unii Europejskiej według WVS.

\section{Tabela 2}

Stopień szczęśliwości według wskaźnika WVS w UE - dane za lata 2005-2008*

\begin{tabular}{|r|r|r|}
\hline $\begin{array}{c}\text { Kraje najmniej szczéśliwe } \\
\text { (wskaźnik WVS <140) }\end{array}$ & $\begin{array}{c}\text { Kraje średnio szczęśliwe } \\
\text { (wskaźnik WVS 140-170) }\end{array}$ & $\begin{array}{r}\text { Kraje najszczéśliwsze } \\
\text { (wskaźnik WVS >170) }\end{array}$ \\
\hline Słowacja $(139,9)$ & Portugalia $(167,3)$ & Szwecja $(192,4)$ \\
Estonia $(133,0)$ & Niemcy $(165,5)$ & Irlandia $(192,2)$ \\
Bułgaria $(115,5)$ & Holandia $(188,0)$ \\
Rumunia $(111,3)$ & Chowenia $(161,1)$ & Luksemburg $(187,9)$ \\
Łotwa $(111,1)$ & Czechy $(157,9)$ & Wielka Brytania $(187,0)$ \\
& Węgry $(150,2)$ & Belgia $(184,7)$ \\
& Grecja $(149,7)$ & Hiszpania $(184,5)$ \\
& Litwa $(142,2)$ & Finlandia $(184,2)$ \\
& & Austria $(180,8)$ \\
& & Francja $(180,5)$ \\
& & Włochy $(179,4)$ \\
& & Polska (179,3) \\
& & Cypr $(174,2)$ \\
& & Malta $(174,0)$ \\
& & Dania $(172,2)$ \\
\hline
\end{tabular}

*W nawiasie podano wartość wskaźnika WVS.

Źródło: Map of Happiness, http://www.jdsurvey.net/jds/jdsurveyMaps.jsp?Idioma=I\&SeccionTexto=040 4\&NOID=103 (dostęp: 31.03.2014).

${ }^{32}$ Części składowe przedstawianych indeksów odzwierciedlają także elementy stanowiące o jakości życia badanych społeczeństw. 
W ramach badań WVS analizowane sa przekonania i wartości ludzi oraz ich odczucia. Analiza szczęśsia w ramach tych badań dotyczy jednak tylko wybranych elementów życia, co może wpływać na ograniczenia w wyciaganiu wniosków. Nie umniejsza to jednak znaczenia przeprowadzanych badań, były one bowiem wykorzystywane chociażby przez ekspertów z Banku Światowego do analizowania związków pomiędzy czynnikami kulturowymi a rozwojem gospodarczym $^{33}$.

2. Badanie Gallup World Poll (GWP) przy analizie pomiaru szczęścia porównuje 155 krajów. Instytut Gallupa przeprowadza sondaże wśród obywateli poszczególnych państw i korzysta z tzw. drabiny Cantrila. Respondenci oceniaja swoje życie w skali od 1 do 10, gdzie 1 oznacza najgorszy stan, a 10 - najlepsze życie. Według danych Instytutu Gallupa za lata 2005-2011 najszczęśliwszym krajem była Dania, a następnie Finlandia, Norwegia, Holandia i Kanada. W tabeli 3 przedstawiono miejsce w rankingu szczęśliwego życia krajów Unii Europejskiej według Gallup World Poll.

\section{Tabela 3}

Lokaty państw UE w rankingu szczęśliwości według Gallup World Poll (2011 r.)

\begin{tabular}{|r|r|}
\hline Kraj (lokata) & Kraj (lokata) \\
\hline Dania (1) & Czechy (36) \\
Finlandia (2) & Grecja (42) \\
Holandia (4) & Malta (46) \\
Szwecja (7) & Słowenia (48) \\
Irlandia (10) & Polska (52) \\
Austria (13) & Słowacja (54) \\
Belgia (15) & Chorwacja (57) \\
Luksemburg (16) & Litwa (59) \\
Wielka Brytania (18) & Estonia(71) \\
Hiszpania (22) & Portugalia (72) \\
Francja (23) & Rumunia (79) \\
Włochy (28) & Węry (95) \\
Niemcy (30) & Eotwa (105) \\
Cypr (35) & Bułgaria (146) \\
\hline
\end{tabular}

Źródło: http://www.earth.columbia.edu/sitefiles/file/Sachs\%20Writing/2012/World\%20Happiness\%20Report.pdf (dostęp: 31.03.2014).

Według badań przeprowadzanych przez Instytut Gallupa respondentów zalicza się do jednej z trzech grup: „kwitnących”, „walczących” lub „cierpiących". Ponadto na podstawie analizy odpowiedzi na pytania dotyczące emocji pozytywnych i negatywnych oceniane sa tzw. codzienne doświadczenia, a ich maksymalna wartość wynosi 10. Dla państw, które uplasowały się w pierwszej piątce rankingu Gallup World Poll, w tabeli 4 przedstawiono udziały poszczególnych grup respondentów, a także ostateczną wartość wskaźnika codziennych doświadczeń. Dla porównania zamieszczono także dane dla Polski.

\footnotetext{
${ }^{33}$ Zob. http://www.worldvaluessurvey.org/WVSContents.jsp (dostęp: 26.08.2014).
} 
Tabela 4

Udziały poszczególnych typów respondentów według Gallup World Poll w pięciu najszczęśliwszych krajach oraz w Polsce w 2010 r.

\begin{tabular}{|l|c|c|c|c|}
\hline \multirow{2}{*}{ Kraj } & \multicolumn{4}{|c|}{ Typ respondentów } \\
\cline { 2 - 5 } & Kwitnący & Walczący & Cierpiący & $\begin{array}{c}\text { Codzienne } \\
\text { doświadczenia }\end{array}$ \\
\hline Dania & $82 \%$ & $17 \%$ & $1 \%$ & 7,9 \\
\hline Finlandia & $75 \%$ & $23 \%$ & $2 \%$ & 7,8 \\
\hline Norwegia & $69 \%$ & $31 \%$ & $0 \%$ & 7,9 \\
\hline Holandia & $68 \%$ & $32 \%$ & $1 \%$ & 7,7 \\
\hline Kanada & $62 \%$ & $36 \%$ & $2 \%$ & 7,6 \\
\hline Polska & $28 \%$ & $61 \%$ & $11 \%$ & 7,1 \\
\hline
\end{tabular}

Źródło: http://www.targetmap.com/viewer.aspx?reportId=2903 (dostęp: 31.03.2014).

Jak można zauważyć, badanie Gallup World Poll dotyczące szczęścia przedstawia subiektywne oceny życia dokonywane przez respondentów. Jednakże pomimo tego, że wydaje się to wąskim ujęciem problemu, często wyniki tych badań wyprzedzają pewne zmiany o charakterze ekonomicznym, społecznym czy politycznym i wskaźniki te mogą stanowić źródło spostrzeżeń niemożliwych do uzyskania za pomocą tradycyjnych wskaźników w analizie przemian społeczno-gospodarczych.

3. Kolejnym narzędziem, które umożliwia tworzenie rankingów państw jest Indeks Postępu Społecznego (Social Progress Index - SPI), uwzględniający w swoich rachunkach z roku 2012 - 50 krajów, a w 2013 - już 132 państwa. Jest to wskaźnik, który mierzy postęp społeczny, jakość życia, dobrobyt, a także może służyć jako narzędzie pomocnicze do oceny szczęścia w społeczeństwach. Obliczany jest na podstawie aktualnych danych pochodzacych m.in. z Banku Światowego i Światowej Organizacji Zdrowia. Indeks SPI powstaje przez obliczenie średniej uzyskanej z analizy trzech kategorii: 1) zaspokojenie fundamentalnych potrzeb człowieka (brane są tutaj pod uwagę: żywność i podstawowa opieka zdrowotna, jakość powietrza, dostęp do wody pitnej i warunki sanitarne, bezpieczne schronienie oraz bezpieczeństwo osobiste); 2) infrastruktura społeczna (tj.: dostęp do podstawowej wiedzy i edukacji, dostęp do informacji i środków komunikacji, zdrowie i dobre samopoczucie, trwałość ekosystemu); 3) możliwość awansu społecznego i wolność osobista (które obejmuja: wolność i prawa osobiste, dostęp do szkolnictwa wyższego, wolność wyboru, równość i tolerancję).

Według rankingu SPI w 2013 r. pierwsze pięć lokat zajęły: Nowa Zelandia (ze wskaźnikiem o wartości 88,24), Szwajcaria $(88,19)$, Islandia $(88,07)$, Holandia $(87,37)$ i Norwegia $(87,12)^{34}$. W tabeli 5 przedstawiono wartości poszczególnych kategorii uwzględnianych przy obliczaniu wskaźnika SPI dla pierwszych pięciu państw w rankingu. Dodatkowo w celu porównania przedstawiono także dane dla Polski.

\footnotetext{
${ }^{34}$ Maksymalna wartość wskaźnika SPI wynosi 100.
} 
Tabela 5

Wartości poszczególnych kategorii wskaźnika SPI w pięciu krajach o najwyższej wartości SPI w 2013 r.

\begin{tabular}{|l|c|c|c|}
\hline \multirow{2}{*}{\multicolumn{1}{|c|}{ Kraj }} & \multicolumn{2}{|c|}{ Kategorie wskaźnika } \\
\cline { 2 - 4 } & $\begin{array}{c}\text { Potrzeby } \\
\text { podstawowe }\end{array}$ & $\begin{array}{c}\text { Infrastruktura } \\
\text { społeczna }\end{array}$ & $\begin{array}{c}\text { Wolność } \\
\text { osobista }\end{array}$ \\
\hline Nowa Zelandia & 91,74 & 84,97 & 88,01 \\
\hline Szwajcaria & 94,87 & 89,78 & 79,92 \\
\hline Islandia & 94,32 & 88,19 & 81,71 \\
\hline Holandia & 93,91 & 87,56 & 80,63 \\
\hline Norwegia & 93,59 & 86,91 & 80,82 \\
\hline Polska & 84,72 & 81,10 & 66,50 \\
\hline
\end{tabular}

Źródło: http://www.socialprogressimperative.org/data/spi\#data_table/countries/spi/dim1,dim2,dim3 (dostęp: 31.03.2014).

Z kolei w tabeli 6 przedstawiono miejsce w rankingu SPI krajów Unii Europejskiej, które uwzględniono w badaniu w 2013 r.

\section{Tabela 6}

Lokaty państw UE w rankingu SPI w 2013 r.*

\begin{tabular}{|r|r|}
\hline Kraj (lokata) & \multicolumn{1}{|c|}{ Kraj (lokata) } \\
\hline Holandia (4) & Portugalia (22) \\
Szwecja (6) & Czechy (23) \\
Finlandia (8) & Słowacja (24) \\
Dania (9) & Polska (27) \\
Austria (11) & Włochy (29) \\
Niemcy (12) & Eotwa (31) \\
Wielka Brytania (13) & Węry (32) \\
Irlandia (15) & Litwa (33) \\
Belgia (17) & Grecja (35) \\
Słowenia (18) & Chorwacja (36) \\
Estonia (19) & Bułgaria (44) \\
Francja (20) & Rumunia (54) \\
Hiszpania (21) & \\
\hline
\end{tabular}

*W tabeli przedstawiono tylko te kraje Unii Europejskiej, które ujęto w badaniu SPI.

Źródło: http://www.socialprogressimperative.org/data/spi\#data_table/countries/spi/dim1,dim2,dim3 (dostęp: 31.03.2014).

Pozycję Polski w rankingu SPI w 2013 r. gwarantował wskaźnik, który ukształtował się na poziomie 77,44.

Wskaźnik SPI odzwierciedla postęp społeczny, który jest z jednej strony niezależny, ale z drugiej skorelowany z rozwojem gospodarczym. SPI odzwierciedla równocześnie poziom zaspokojenia potrzeb człowieka, możliwości realizacji tych potrzeb oraz podstawy dobrobytu. Analizy SPI wskazują na różnice 
między krajami pod względem tych aspektów społecznych oraz eksponują ich słabe i mocne strony w poszczególnych państwach, co może być wykorzystane w tworzeniu krajowych programów politycznych.

4. Światowy Indeks Szczęścia (Happy Planet Index - HPI) to często przytaczany w literaturze przedmiotu sposób pomiaru szczęścia w społeczeństwie (liczony dla 151 państw). Na wartość HPI składaja się trzy czynniki: subiektywny (czyli średnie zadowolenie z całości życia mieszkańców danego kraju), obiektywny (tj. oczekiwana długość życia w dniu narodzin) oraz miernik korzystania z zasobów (interpretowany jako obszar lądu, potrzebny do tego, aby rosnące na nim rośliny wchłonęły i unieszkodliwiły dwutlenek węgla emitowany podczas wykorzystania paliw kopalnych $\mathrm{w}$ danym kraju, w zależności od poziomu konsumpcji). Wskaźnik HPI został opracowany w 2006 r. i liczony jest według wzoru:

HPI = (odczuwany dobrostan x oczekiwana długość życia) / ślad ekologiczny

Według raportu HPI z 2012 r. najszczęśliwszym krajem na świecie była Kostaryka (ze wskaźnikiem na poziomie 64,0), na drugim miejscu - Wietnam $(60,4)$, na trzecim - Kolumbia $(59,8)$, na czwartym - Belize $(59,3)$, a na piątym - Salwador $(58,9)$.

W tabeli 7 przedstawiono wartości składowe wskaźnika HPI dla pięciu najszczęśliwszych państw na świecie (a dla porównania dodano także te wartości dla Polski).

Tabela 7

Wartości poszczególnych kategorii składowych wskaźnika HPI w pięciu najszczęśliwszych krajach w 2012 r.

\begin{tabular}{|l|c|c|c|}
\hline \multirow{2}{*}{\multicolumn{1}{|c|}{ Kraj }} & \multicolumn{3}{|c|}{ Składowe wskaźnika } \\
\cline { 2 - 4 } & $\begin{array}{c}\text { Odczuwany } \\
\text { dobrostan } \\
\text { (max. 10) }\end{array}$ & $\begin{array}{c}\text { Oczekiwana } \\
\text { długość życia } \\
\text { (w latach) }\end{array}$ & $\begin{array}{c}\text { Ślad } \\
\text { ekologiczny } \\
\text { (w gha/osobę) }\end{array}$ \\
\hline Kostaryka & 7,3 & 79,3 & 2,5 \\
\hline Wietnam & 5,8 & 75,8 & 1,4 \\
\hline Kolumbia & 6,4 & 73,7 & 1,8 \\
\hline Belize & 6,5 & 76,1 & 2,1 \\
\hline Salwador & 6,7 & 72,2 & 2,0 \\
\hline Polska & 5,8 & 76,1 & 3,9 \\
\hline
\end{tabular}

Źródło: http://www.happyplanetindex.org/data/ (dostęp: 31.03.2014).

Przeciętna wartość wskaźnika HPI w 2012 r. wynosiła 42,5. W tabeli 8 przedstawiono także lokaty krajów Unii Europejskiej w rankingu HPI. 


\section{Tabela 8}

Wartości wskaźnika i lokaty państw UE w rankingu szczęśliwości według HPI w 2012 r.

\begin{tabular}{|c|c|c|}
\hline Kraj & Lokata w rankingu HPI & Wartość wskaźnika HPI \\
\hline Wielka Brytania & 41 & 47,9 \\
\hline Niemcy & 46 & 47,2 \\
\hline Austria & 48 & 47,1 \\
\hline Francja & 50 & 46,5 \\
\hline Włochy & 51 & 46,4 \\
\hline Szwecja & 52 & 46,2 \\
\hline Cypr & 59 & 45,5 \\
\hline Hiszpania & 62 & 44,1 \\
\hline Malta & 66 & 43,1 \\
\hline Holandia & 67 & 43,1 \\
\hline Finlandia & 70 & 42,7 \\
\hline Polska & 71 & 42,6 \\
\hline Irlandia & 73 & 42,4 \\
\hline Rumunia & 75 & 42,2 \\
\hline Chorwacja & 81 & 40,6 \\
\hline Grecja & 83 & 40,5 \\
\hline Słowenia & 87 & 40,2 \\
\hline Słowacja & 89 & 40,1 \\
\hline Czechy & 92 & 39,4 \\
\hline Portugalia & 97 & 38,7 \\
\hline Węgry & 104 & 37,4 \\
\hline Belgia & 107 & 37,1 \\
\hline Dania & 110 & 36,6 \\
\hline Estonia & 117 & 34,9 \\
\hline Łotwa & 118 & 34,9 \\
\hline Litwa & 120 & 34,6 \\
\hline Bułgaria & 123 & 34,1 \\
\hline Luksemburg & 138 & 29,0 \\
\hline
\end{tabular}

Źródło: http://www.happyplanetindex.org/data/ (dostęp: 31.03.2014).

Wskaźnik HPI charakteryzuje się przejrzystą formułą obliczania. Łączy w sobie zarówno twarde, jak i miękkie kryteria oceny szczęścia w społeczeństwach. Wydaje się jednak, że ten wskaźnik ma pewne wady. Jako jedna z nich można wskazać to, że pojęcie szczęścia czy też zadowolenia z życia to wielkości subiektywne i osobiste, często uwarunkowane kulturowo, zatem trudno tutaj mówić o porównaniach w skali światowej. Inną kwestia 
jest także sama nazwa, z jednej strony bowiem jest to indeks szczęśliwości, który wynika z odczuć społeczeństwa, ale również, jak wskazuje formuła obliczeniowa, w dużej mierze kształtowany jest elementami środowiska naturalnego.

5. Jeszcze jednym przykładowym sposobem mierzenia dobrobytu, jakości życia, a pośrednio szczęścia w społeczeństwach jest Indeks Lepszego Życia (Better Life Index - BLI) opracowany przez OECD i liczony od 2011 r. W kalkulacji BLI brane sa pod uwagę warunki mieszkaniowe, dochody, praca, społeczeństwo, edukacja, środowisko, społeczne zaangażowanie, zdrowie, satysfakcja, bezpieczeństwo, równowaga praca-życie dla 34 krajów członkowskich, a także Rosji i Brazylii.

Według szacunków OECD najwyższy wskaźnik BLI w 2012 r. uzyskały: Australia, Szwecja, Kanada, Norwegia i Szwajcaria. W tabeli 9 przedstawiono wartości składowe wskaźnika BLI dla tych pięciu państw (dla porównania dodano także dane dla Polski).

\section{Tabela 9}

Udziały poszczególnych składowych wskaźnika BLI w pięciu krajach o najwyższych wartościach BLI w 2012 r. oraz dla Polski*

\begin{tabular}{|l|c|c|c|c|c|c|}
\hline \multirow{2}{*}{$\begin{array}{c}\text { Składowe } \\
\text { wskaźnika }\end{array}$} & \multicolumn{5}{|c|}{ Kraj } \\
\cline { 2 - 7 } & Australia & Szwecja & Kanada & Norwegia & Szwajcaria & Polska \\
\hline $\begin{array}{l}\text { Warunki } \\
\text { mieszkaniowe }\end{array}$ & 7,6 & 6,2 & 7,8 & 7,4 & 6,0 & 3,1 \\
\hline Dochody & 4,6 & 4,7 & 5,9 & 3,9 & 7,8 & 1,1 \\
\hline Praca & 7,7 & 7,2 & 7,7 & 8,6 & 8,9 & 5,2 \\
\hline Społeczeństwo & 8,3 & 7,6 & 8,4 & 8,0 & 8,6 & 7,2 \\
\hline Edukacja & 7,6 & 8,3 & 7,6 & 7,2 & 7,3 & 7,9 \\
\hline Środowisko & 8,8 & 9,7 & 8,4 & 9,2 & 8,3 & 5,3 \\
\hline $\begin{array}{l}\text { Społeczne } \\
\text { zaangażowanie }\end{array}$ & 9,5 & 8,7 & 6,1 & 6,4 & 3,6 & 5,5 \\
\hline Zdrowie & 9,3 & 8,8 & 9,2 & 8,1 & 9,3 & 5,0 \\
\hline Satysfakcja z życia & 8,1 & 9,3 & 8,8 & 9,7 & 10,0 & 3,9 \\
\hline Bezpieczeństwo & 9,5 & 8,2 & 9,7 & 9,1 & 8,7 & 9,6 \\
\hline $\begin{array}{l}\text { Równowaga praca- } \\
\text {-życie }\end{array}$ & 6,6 & 8,8 & 7,5 & 9,1 & 7,9 & 7,1 \\
\hline
\end{tabular}

*Maksymalna wartość wskaźnika w poszczególnych kategoriach wynosi 10.

Źródło: OECD Better Life Index, http://www.oecdbetterlifeindex.org (dostęp: 31.03.2014).

W tabeli 10 przedstawiono miejsce w rankingu OECD tych krajów Unii Europejskiej, które zostały ujęte w badaniu BLI w 2012 r. 
Tabela 10

Lokaty państw UE w rankingu Better Life Index OECD z 2012 r.

\begin{tabular}{|r|r|}
\hline Kraj (lokata) & Kraj (lokata) \\
\hline Szwecja (2) & Słowenia (19) \\
Dania (7) & Hiszpania (20) \\
Holandia (8) & Czechy (22) \\
Wielka Brytania (10) & Włochy (23) \\
Finlandia (12) & Polska (25) \\
Austria (13) & Słowacja (26) \\
Luksemburg (14) & Portugalia (28) \\
Irlandia (15) & Węry (29) \\
Belgia (16) & Grecja (30) \\
Niemcy (17) & Estonia (31) \\
Francja (18) & \\
\hline
\end{tabular}

Źródło: OECD Better Life Index, http://www.oecdbetterlifeindex.org/ (dostęp: 31.03.2014).

Wskaźnik BLI umożliwia porównanie dobrobytu w poszczególnych krajach na podstawie jedenastu aspektów życia, ale przede wszystkim identyfikuje istotne elementy w zakresie materialnych warunków życia i jakości życia. Wskaźnik na pewno stanowi ważny wkład do badań nad jakością życia i inicjatyw zmierzających do jej poprawy, wprowadza nowe spojrzenie na dobór i sposób rozwoju wskaźników dobrobytu oraz stanowi próbę wdrożenia nowych ram pomiarowych szczęścia.

$$
* * *
$$

Powyższe wskaźniki mierzące jakość życia i satysfakcję z życia, a także starające się uchwycić poziom szczęścia w społeczeństwach obejmują wielorakie obszary życia społecznego i wydają się bardzo interesujące w dyskusji nad jednoczesnym rozumieniem postępu i szczęścia społeczeństw. Przedstawione rankingi nie gwarantuja jednak jednoznacznych odpowiedzi, na pytanie, które ze społeczeństw są najszczęśliwsze.

Problematyczność zagadnienia, jakim jest szczęście i jego pomiar w ekonomii, jeszcze bardziej uwidacznia porównywanie wyników rankingów szczęśliwości z podstawową kategorią oceniającą przeciętny standard życiowy ludności - PKB per capita. Porównanie powyższych rankingów z rankingiem krajów przedstawianym przez Międzynarodowy Fundusz Walutowy według PKB per capita z 2012 r. pozwala zauważyć, że zbieżność wyników występuje tylko w przypadku Norwegii, która z reguły plasuje się w pierwszej piątce państw zarówno w rankingach szczęścia, jak i według szacunków MFW. Do krajów, które zajmują wysoką pozycję w prezentowanych rankingach, a które to równocześnie znajdują się w pierwszej dziesiątce państw świata pod względem PKB per capita, należą także Szwajcaria oraz Kanada. W przypadku pozostałych państw różnice te są już bardziej znaczące. Największe dotyczą szacunków HPI i MFW. Kraje, które uzyskały dominujące pozycje według indeksu HPI, niestety według PKB per capita znajdują się daleko poza czołówka - Ko- 
staryka zajmuje 76 miejsce, Wietnam - 134, a Kolumbia - 85. Zatem różnice w lokatach państw według rankingów szczęśliwości i rankingu PKB per capita wskazują często na zupełnie sprzeczne względem siebie informacje ${ }^{35}$.

Jeszcze jedną istotną kwestią w analizowaniu wskaźników szczęścia czy też jakości życia, na którą należy zwrócić uwagę, jest fakt, że część z tych wskaźników jest całkowicie odporna na polityczne manipulacje, część z nich zaś w dużej mierze im podlega. Powoduje to, że pojawia się niebezpieczeństwo relatywizowania pojęć subiektywnych, takich jak szczęście czy też poczucie zadowolenia, ale także takich pojęć, jak: rozwój, potencjał, demokracja czy poziom cywilizacyjny itp., w danym kraju. Ta kwestia na pewno wymagałaby znacznego rozszerzenia w dywagacjach naukowych.

\section{PODSUMOWANIE}

Na podstawie powyższych rozważań można stwierdzić, że istnieją wskaźniki szczęścia, ale nie pozwalają one na uzyskanie jednoznacznej odpowiedzi na pytanie zawarte we wstępie artykułu. Należy pamiętać, że żaden ze sposobów obliczania poziomu szczęścia nie jest w pełni trafny, rzetelny i wystarczający. Przedstawione powyżej sposoby opisu szczęścia w społeczeństwach powinny być zatem traktowane komplementarnie, powinny uzupełniać się i wzajemnie korygować nie tylko ze soba, lecz także ze wskaźnikami jakości życia.

Wszelkiego rodzaju rankingi (w tym także rankingi szczęśliwości) maja niewątpliwą zaletę - każdy z nich dostarcza jednoznacznej odpowiedzi. Wadą sa z kolei znaczne uproszczenia polegające chociażby na tym, że do obliczania wskaźników stosuje się wybrane dane. Niemożliwe zatem jest zbudowanie jednego, wielowymiarowego wskaźnika szczęścia do porównań międzynarodowych. Wynika to zarówno z doboru danych, jak i aspektów społecznych, kulturowych, ekonomicznych, politycznych czy historycznych ${ }^{36}$.

Skoro zatem nie ma jednej definicji szczęścia, nie ma również jednego sposobu jego pomiaru. Szczęście z naukowego punktu widzenia nie jest pojęciem obiektywnym, dotyczy bowiem jednostki oraz jej odczuć i nie można go zmierzyć ekonomicznie. Nadal trwa jednak interdyscyplinarna dyskusja nad możliwościami jego pomiaru w społeczeństwie i można w tym miejscu podkreślić stwierdzenie z początku artykułu, że znaczący udział w tej dyskusji mają również przedstawiciele nauk ekonomicznych.

dr hab. Katarzyna Wtodarczyk

Uniwersytet Szczeciński

kwlod@wneiz.pl

${ }^{35}$ Międzynarodowy Fundusz Walutowy, World Economic Outlook Database, April 2014, http://www.imf.org/external/index.htm (dostęp: 12.04.2014).

${ }^{36}$ Por. T. Kuszewski, A. Siekielska, Użyteczna sztuka rankingów ekonomiczno-społecznych, „Współczesna Ekonomia” 2010, nr 1(13), s. 143-162. 


\section{ECONOMICS IN RELATION TO HAPPINESS}

\section{Sum mary}

As far as a discussion on happiness is concerned, economics is a field that has made a considerable contribution, although in formulating their views economists also take into account of conclusions drawn by researchers in other disciplines. The main aim of the paper is to answer the following question: Can happiness be measured?

The paper refers to the main theses and controversial issues dealt with by the economics of happiness. However, the notion of happiness has not been defined explicitly and methods for measuring its level are disputable and arouse controversy. Still, interdisciplinary research conducted globally has contributed to the development of a number of indexes measuring happiness. These indexes are used for preparing global rankings of the happiest societies. Indexes of happiness are frequently related to the evaluation of the quality of life. In the article attention is paid to selected indexes measuring happiness, satisfaction and the quality of life such as: World Value Survey WVS, Gallup World Poll (GWP), Social Progress Index (SPI), Happy Planet Index (HPI) and Better Life Index (BLI).

Based on the discussion presented in the article, it can be stated that the available happiness indexes do not provide unequivocal answers. Admittedly, no method for determining the level of happiness, satisfaction and quality of life is perfectly accurate, reliable and satisfactory. It is beyond any doubt that the means for describing and measuring social happiness and quality of life should be mutually complementary and corrective. 
Copyright of Journal of Law, Economics and Sociology is the property of Faculty of Law and Administration of Adam Mickiewicz University in Poznan and its content may not be copied or emailed to multiple sites or posted to a listserv without the copyright holder's express written permission. However, users may print, download, or email articles for individual use.

Właścicielem praw autorskich do „Ruchu Prawniczego, Ekonomicznego i Socjologicznego” jest Wydział Prawa i Administracji Uniwersytetu im. Adama Mickiewicza w Poznaniu. Zawartość czasopisma nie może być kopiowana, przesyłana do innych stron internetowych bądź zamieszczana na blogach bez pisemnej zgody wydawcy. Niemniej artykuły można drukować, kopiować lub przesyłać w formie elektronicznej na własny użytek. 